\title{
Arsenic efflux and its role in As tolerance in As-hyperaccumulators
} Masayoshi Hatayama*

Graduate School of Environmental Studies, Tohoku University, Japan

Arsenic (As) disturbs the primary metabolism of an organism, which is detrimental [1]. For that reason, organisms have evolved various mechanisms of As tolerance such as extrusion, intracellular compartmentalization, repression of transporters, and a high tolerance to reactive oxygen species and it is important to understand the mechanisms to conquer its toxicity.

An As-hyperaccumulator, Pteris vittata, is a type of plant that is able to accumulate 100 times more As than normal plants or organisms that use the normal mechanisms mentioned above for As tolerance. The fern not only tolerates As in very high concentrations, but also predominantly accumulates it in the form of arsenite (AsIII), which is a more toxic form of the As oxyanion. The accumulation level of non-hyperaccumulators differs from those of non-hyperaccumulating organisms. However, each of the known mechanisms for As tolerance have been observed in various degrees or in certain parts of Ashyperaccumulators, and it is not clear which strategy or combination thereof is most effective for the tolerance of As by a plant.

In ancient times, when the primitive earth had no oxygen and was under reductive conditions, it was assumed that bacteria first developed and acquired a tolerance to AsIII, which predominates under reductive conditions. Tolerance is achieved by exporting such toxic AsIII from a single cell. For example, in Sinorhizobium meliloti, AsIII is excreted from the cell via aquaglyceroporin, AqpS [2], and the tolerance system for arsenate $(\mathrm{AsV})$, such as $\mathrm{AsV}$ reductase is considered to be acquired under latter oxidative conditions. Unlike bacterium, eukaryotic cells have no intercellular organs, such as plastids or vacuoles (lysosomes), in which to compartmentalize As. In the Saccharomyces cerevisiae system, AsIII is conjugated using a thiol compound, glutathione (GSH), and either sequestered into the vacuolar lumen as an As-(GS)3 complex or excreted from the cell by AsIII transporters as with bacteria [3].

For plants, inorganic As species AsV and AsIII, and organic forms of As such as MMA and DMA, are available from the soil [4]. Of those, $\mathrm{AsV}$ is the dominant species incorporated into plants via the phosphate $(\mathrm{Pi})$ transport pathway, as $\mathrm{AsV}$ is a chemical analogue of $\mathrm{Pi}$. The subsequent metabolism of $\mathrm{AsV}$ by terrestrial plants has been studied [5]. Similar to S.cerevisiae, after the incorporation of AsV into the cell, AsV is transformed to AsIII by AsV reductase. AsIII is simply excreted from the cell via aquaporin [6,7] or conjugated either by GSHs or phytochelatins in the plant [8]; then, it is likely sequestered into the vacuolar lumen by glutathione-S-transferase [9]. In a similar manner, several plants produce thiol compounds for the detoxification of AsIII $[10,11]$ or repress the AsV uptake system by the roots [5,11]. In aquatic plants, an increase in thiol compounds has been observed in response to As exposure and a similar mechanism could be considered for As detoxification $[12,13]$.

However, in the As-hyperaccumulating plants, the role of thiol 1 compounds for AsIII detoxification is considered to be very small $[8,14]$. As species in those plants and the behavior of As in the plant body is distinct from that in other plants. Normally, As accumulation in plants mostly range from 5-100 (Kabata-Pendias and Pendias, 1992) and mostly less than $1 \mathrm{mg} / \mathrm{kg}$ in the leaf. In those particular plants, As accumulation was 100 times more than normal plants with an accumulation of the most-toxic AsIII found at the shoot [15].
Since much toxic AsIII is a dominant As species in the shoot, compartmentalization of AsIII in the shoot cell is considered one of the possible mechanisms of detoxification of AsIII in P. vittata. Energy dispersive X-ray microanalyses (EDXA) of frond cells has shown that a part of As is localized in the subcellular compartment, which corresponds to a vacuole in epidermal cells [16]. For gametophytes, AsIII was clearly localized in the vacuolar lumen, whereas AsV was possibly moved into the cytosol [17]. Further, the AsIII membrane transport protein, (tonoplast intrinsic protein) TIP, which directly transports AsIII into the vacuolar lumen, was isolated and characterized [18]. However, the expression of the AsIII transporter was limited to root tips when exposed to As and no expression was observed in the shoot. Thus, the compartmentalization of AsIII into the vacuole might not be the best of the adaptive strategies for As tolerance by the frond cell of $P$. vittata.

AsIII efflux from the root cell is known to be effective for AsIII detoxification. The role of AsIII efflux for As detoxification is significant in the A. thaliana root. In this plant, AsV taken up by the roots almost exits the root as an AsIII species within $24 \mathrm{hrs}$ [19]. Additionally, a membrane transport protein of the aquaporin family, which is responsible for AsIII efflux in the root of A. thaliana, is localized 1 on the plasma membrane of root tips [18]. It might be possible that $\mathrm{AsV}$, which was taken up by Pi transporters, pht1:1 and pht1:4 [20] in A. thaliana were efficiently reduced to AsIII in the root cells and excreted to the external environment. For As-hyperaccumulators, AsIII efflux was also observed, but at a lower rate by comparison with non-hyperaccumulators such as A. thaliana [21,22]. Additionally, the excretion of $\mathrm{AsV}$ has been observed in As hyperaccumulators. However, $\mathrm{AsV}$ efflux is also lower in As-hyperaccumulators. The low efflux of AsIII and AsV contributes to the As accumulation in the plant and most of the incorporated As is efficiently translocated (loaded) to the shoot. The idea of As efflux from a cell can be extended to shoot cells, not only to the root. AsIII efflux is conserved among various plants such as rice [23], tomatoes [24], and rootless duckweed [25]. If As is excreted from the shoot cell, this could be helpful for As detoxification. This speculation is supported by the results from the suspension cell culture of $P$. vittata. A callus exhibited approximately three times more As accumulation than A. thaliana callus [26]. However, maximal accumulation of the cell cultures in this study seemed to be around $1,000 \mathrm{mg} / \mathrm{kg} \mathrm{DW}$, while the entire plant of $P$. vittata can accumulate a maximum of 22,630 mg/kg DW of As [15]. Based on this observation, As tolerance by the pinna cells is lower than the maximum accumulation exhibited by the entire plant. It is also clear that high tolerance to

*Corresponding author: Masayoshi Hatayama, Graduate School of Environmental Studies, Tohoku University, Aoba 6-6-20, Aoba, Sendai, Miyagi, 980-8579, Japan, E-mail: masa_use@hotmail.com

Received May 02, 2012; Accepted May 02, 2012; Published May 04, 2012

Citation: Hatayama M (2012) Arsenic efflux and its role in As tolerance in Ashyperaccumulators. Bioenergetics 1:e104. doi:10.4172/2167-7662.1000e104

Copyright: ( 2012 Hatayama M. This is an open-access article distributed under the terms of the Creative Commons Attribution License, which permits unrestricted use, distribution, and reproduction in any medium, provided the original author and source are credited. 
oxidative stress is one of the significant factors for AsIII tolerance in $P$. vittata. Singh et al. found a higher tolerance from oxidative damage for $P$. vittata than for other non-hyperaccumulating ferns when exposed to As [27], which was not as high as expected, however, based on the differences in As accumulation 1 between the hyperaccumulators [15] and non-hyperaccumulators.

When we consider the AsIII efflux from the pinna cell, it seems there is no AsIII efflux to the apoplastic space, since there is no significant accumulation in the cell wall and in the apoplastic fluid [16]. Thus, the efflux of AsIII to the phloem of the companion cell is suggested. There are a few reports of the phloem transport of As. In the Castor bean, As was detected in the phloem sap [28], and, in rice, the phloem transport of As from the flag leaf to the grain was observed [29], but the As species accumulated in those examples were not AsIII. Also, there is a difference in As accumulation between the young and the mature frond. The lower As-accumulation in the frond could be a sink for the As expected from the source frond. Further research at the cellular level and in the behavior of As at the whole plant level should be conducted in the future.

\section{References}

1. Christen K (2001) The arsenic threat worsens. Environ Sci Technol 35 286A-291A.

2. Yang HC, Cheng J, Finan TM, Rosen BP, Bhattacharjee H (2005) Novel pathway for arsenic detoxification in the legume symbiont Sinorhizobium meliloti. J Bacteriol 187: 6991-6997.

3. Rosen BP (2002) Biochemistry of arsenic detoxification. FEBS Lett 529: 86-92.

4. Moreno-Jiménez E, Esteban E, Peñalosa JM (2012) The fate of arsenic in soilplant systems. Rev Environ Contam Toxicol 215: 1-37.

5. Meharg AA, Hartley-Whitaker J (2002) Arsenic uptake and metabolism in arsenic resistant and non resistant plant species. New Phytologist 154: 29-43.

6. Bienert GP, Thorsen M, Schüssler MD, Nilsson HR, Wagner A, et al. (2008) A subgroup of plant aquaporins facilitate the bi-directional diffusion of $\mathrm{As}(\mathrm{OH}) 3$ and $\mathrm{Sb}(\mathrm{OH}) 3$ across membranes. BMC Biol 6:26.

7. Kamiya T, Tanaka M, Mitani N, Ma JF, Maeshima M, et al. (2009) NIP1;1, an aquaporin homolog, determines the arsenite sensitivity of Arabidopsis thaliana. J Biol Chem 284: 2114-2120.

8. Raab A, Feldmann J, Meharg AA (2004) The nature of arsenic-phytochelatin complexes in Holcus lanatus and Pteris cretica. Plant Physiol 134: 1113-1122.

9. Paulose B, Kandasamy S, Dhankher OP (2010) Expression profiling of Crambe abyssinica under arsenate stress identifies genes and gene networks involved in arsenic metabolism and detoxification. BMC Plant Biol 10: 108.

10. Schmoger ME, Oven M, Grill E (2000) Detoxification of arsenic by phytochelatins in plants. Plant Physiol 122: 793-801.

11. Hartley-Whitaker J, Ainsworth G, Vooijs R, Bookum WT, Schat H, et al. (2001) Phytochelatins Are Involved in Differential Arsenate Tolerance in Holcus lanatus. Plant Physiol 126: 299-306.

12. Srivastava S, Mishra S, Tripathi RD, Dwivedi S, Trivedi PK, et al. (2007) Phytochelatins and antioxidant systems respond differentially during arsenite and arsenate stress in Hydrilla verticillata (L.f) Royle. Environ Sci Technol 41: 2930-2936.

13. Mishra S, Srivastava S, Tripathi RD, Trivedi PK (2008) Thiol metabolism and antioxidant systems complement each other during arsenate detoxification in Ceratophyllum demersum L. Aquat Toxicol 86: 205-215.

14. Zhao FJ, Wang JR, Barker JHA, Schat H, Bleeker PM, et al. (2003) The role of phytochelatins in arsenic tolerance in the hyperaccumulator Pteris vittata. New Phytologist 159: 403-410.

15. Ma LQ, Komar KM, Tu C, Zhang W, Cai Y, et al. (2001) A fern that hyperaccumulates arsenic. Nature 409: 579

16. Lombi E, Zhao FJ, Fuhrmann M, Ma LQ, McGrath SP (2002) Arsenic distribution and speciation in the fronds of the hyperaccumulator Pteris vittata. New Phytologist 156: 195-203.
17. Pickering IJ, Gumaelius L, Harris HH, Prince RC, Hirsch G, et al. (2006) Localizing the biochemical transformations of arsenate in a hyperaccumulating fern. Environ Sci Technol 40: 5010-5014.

18. Indriolo E, Na G, Ellis D, Salt DE, Banks JA (2010) A vacuolar arsenite aransporter necessary for arsenic tolerance in the arsenic hyperaccumulating fern Pteris vittata is missing in flowering plants. Plant Cell 22: 2045-2057.

19. Liu WJ, Wood BA, Raab A, McGrath SP, Zhao FJ, et al. (2010) Complexation of arsenite with phytochelatins reduces arsenite efflux and translocation from roots to shoots in Arabidopsis. Plant Physiol 152: 2211-2221.

20. Shin H, Shin HS, Dewbre GR, Harrison MJ (2004) Phosphate transport in Arabidopsis: Pht 1;1 and Pht1;4 play a major role in phosphate acquisition from both low- and high-phosphate environments. Plant J 39: 629-642.

21. Su YH, McGrath SP, Zhu YG, Zhao FJ (2008) Highly efficient xylem transport of arsenite in the arsenic hyperaccumulator Pteris vittata. New Phytol 180: 434441

22. Huang $Y$, Hatayama M, Inoue C (2011) Characterization of As efflux from the roots of As hyperaccumulator Pteris vittata L. Planta 234: 1275-1284.

23. Zhao FJ, Ago Y, Mitani N, Li RY, Su YH, et al. (2010) The role of the rice aquaporin Lsi1 in arsenite efflux from roots. New Phytol 186: 392-399.

24. Xu XY, McGrath SP, Zhao FJ (2007) Rapid reduction of arsenate in the medium mediated by plant roots. New Phytol 176: 590-599.

25. Zhang X, Zhao FJ, Huang Q, Williams PN, Sun GX, et al. (2009) Arsenic uptake and speciation in the rootless duckweed Wolffia globosa. New Phytol 182: 421 428.

26. Yang X, Chen H, Xu W, He Z, Ma M (2007) Hyperaccumulation of arsenic by callus, sporophytes and gametophytes of Pteris vittata cultured in vitro. Plant Cell Rep 26: 1889-1897.

27. Singh N, Ma LQ, Srivastava M, Rathinasabapathi B (2006) Metabolic adaptations to arsenic-induced oxidative stress in Pteris vittata $L$ and Pteris ensiformis L. Plant Science 170: 274-282.

28. Ye WL, Wood BA, Stroud JL, Andralojc PJ, Raab A, et al. (2010) Arsenic speciation in phloem and xylem exudates of castor bean. Plant Physiol 154: 1505-1513.

29. Carey AM, Norton GJ, Deacon C, Scheckel KG, Lombi E, et al. (2011) Phloem transport of arsenic species from flag leaf to grain during grain filling. New Phytol 192: 87-98. 